\title{
COLLAPSE OF BASE SOIL AND ITS CONSEQUENCES DURING A CEMENT PLANT CONSTRUCTION
}

\author{
${ }^{1}$ Volkan KALPAKCI \\ ${ }^{1}$ Civil Engineering Department, Hasan Kalyoncu University, Gaziantep, Turkey \\ ${ }^{1}$ volkan.kalpakci@hku.edu.tr
}

(Geliş/Received: 21.03.2017; Kabul/Accepted in Revised Form: 14.04.2017)

\begin{abstract}
Collapsible soils are subjected to rapid changes in their volume when inundated with water. Collapse of such a soil deposit during construction of a cement plant in north Azerbaijan resulted in significant settlement and tilting of structures causing a 2 years delay in the construction. The investor had to bear the huge costs of delay and remediation works. The collapse susceptibility of the soil could not be identified during initial site investigations. After first indications of the collapse problem (tilting, cracking of structures) the settlements were measured at different locations for a long time and a new site investigation was executed. The results of these studies were utilized to determine the collapse potential of the soil. Interestingly, some of the indirect methods were not capable of determining the collapse potential. It was seen that, indirect methods may mislead the engineers in such soils and it is more reliable to perform direct tests to determine collapse potential in similar soil deposits. In this study, it is aimed to discuss the experience gained in this project about determining the collapse potential and apprise the professionals as well as academicians about possible problems which may be faced during such studies in similar soils.
\end{abstract}

Key Words: Collapse, Settlement, Tilt

\section{Bir Çimento Fabrikası İnşaatı Sırasında Gözlemlenen Zemin Çökmeleri ve Sonuçları}

ÖZ: Çökebilen zeminler suya maruz kaldıklarında hacimsel olarak hızlı değişimler gösterirler. Kuzey Azerbaycan'daki bir çimento fabrikası inşaatı sırasında meydana gelen bu tarz bir zemin çökmesi, yapıların kayda değer miktarda oturmasına ve eğilmesine sebep olmuş ve inşaatın yaklaşık 2 yıl kadar gecikmesine sebebiyet vermiştir. Yatırımcı, tamirat işleri ve gecikmeler sebebiyle oluşan ciddi maliyetleri karşılamak zorunda kalmıştır. Zeminin çökme potansiyeli yapılan ilk saha etütlerinde belirlenememiştir. Eğilme ve/veya yapılardaki çatlaklar gibi çökmeden kaynaklı ilk belirtilerden sonra, çeşitli noktalarda uzun süreli oturma ölçümleri alınmış ve yeni, daha detaylı arazi etütleri planlanmıştır. Bu çalışmaların sonuçları, zeminin çökme potansiyelini belirlemek için kullanılmıştır. Literatürde belirtilen dolaylı metotların bazıları ilginç bir şekilde çökme potansiyelini belirleyememiştir. Yapılan araştırma sonucunda, bu tip zeminlerde bazı metotların mühendisleri yanlış sonuçlara yönlendirebileceği; benzer zeminlerde çökme potansiyelini direk metotlarla belirlemenin daha güvenilir bir yöntem olduğu görülmüştür. Bu çalışmanın amacl, projede sırasında bu tip zeminlerin çökme potansiyelinin belirlenmesi konusunda kazanılmış tecrübeleri tartışmak ve hem akademisyenleri hem de bu alandaki profesyonel kişileri benzer zeminlerde, bu tarz çalışmalar sırasında oluşabilecek sorunlar hakkında bilgilendirmektir. 


\section{INTRODUCTION}

The rapid decrease in total volume of a soil due to wetting-induced breakdown of its structure under constant total vertical stress is commonly referred to "collapse" of that soil. Factors affecting the collapse potential of a soil deposit may be listed as the mineralogy, gradation, in situ density and moisture content of the soil as well as the nature of cementing agents, pore fluid chemistry and the degree of inundation with water. In general, it can be said that soils with water soluble contents (salt, gypsum, etc.) and low dry density have a collapse potential that should be investigated before the construction. The properties of collapsible soils and the potential methods for prediction of the collapse susceptibility of a soil were previously studied by many different researchers some of which may be listed as Priklonski (1952), Larionov (1965), Gibbs and Bara (1967), Handy (1973), Lin and Liyang (1982), Houston et al. (1988), Lawton et al. (1992). A more recent method was suggested to determine the collapse potential by Ayadat and Hanna (2007). In Ayadat and Hanna (2007), an empirical model was developed for predicting soil collapse in terms of the initial dry unit weight, initial water content and the soil gradation. Collapse potential of loess soils were investigated by Hormdee (2008). In this study, it was stated that these soils are found in arid regions and goes under significant volume loss when saturated resulting in severe damages to structures due to differential settlements, just as seen in this case.

Collapse of base soils were responsible for significant damages in constructed facilities. A real scale foundation was constructed on a collapsible soil and the settlements were observed in El-Ehwany and Houston (1990), while damage at highway infrastructure due to collapsible soils was discussed in Houston et al. (2002). The collapse potential of approach pavements in 74 bridges in Iowa, USA was investigated in White et al. (2007). The collapse of base soil and its consequences in Abu Mena historical site in Egypt, was discussed in Benedini and Cleere (2005) and Herle et al. (2010). In Volgodonsk city of Russia, having similar soil characteristics with the presented case, settlements up to $30 \mathrm{~cm}$ and $90 \mathrm{~cm}$ were reported beneath structures resting on mat and piled foundations respectively by Grigoryan (1991).

Collapsible soils are frequently observed in countries around Black Sea and Middle Asia. These soils are typically loamy and clayey loess deposits having gypsum, salt and mica contents which are highly soluble when subjected to water. Such soils seem to be very stiff during dry seasons but they lose their integrity and stiffness very rapidly when inundated with rains resulting in excessive settlements.

Extensive settlements due to collapse of such a soil deposit during construction of a cement plant in north Azerbaijan (Fig.1) and its consequences are discussed in this study. The cement plant consists of several structural units including towers and heavy foundations covering an area of $1450 \mathrm{~m} \times 850 \mathrm{~m}$. The collapsible soils were not emphasized during the geotechnical design. Structures were built on $16 \mathrm{~m}$ deep piled foundations which were designed by conventional bearing capacity calculation methods. Large settlements and tilting of structures were observed at the early stages of the construction. The structural damage due to soil collapse led to a delay of approximately 2 years in the construction. Moreover, the investor had to bear the huge costs of this delay together with the costs for repair of the existing parts and soil improvement for further construction. 


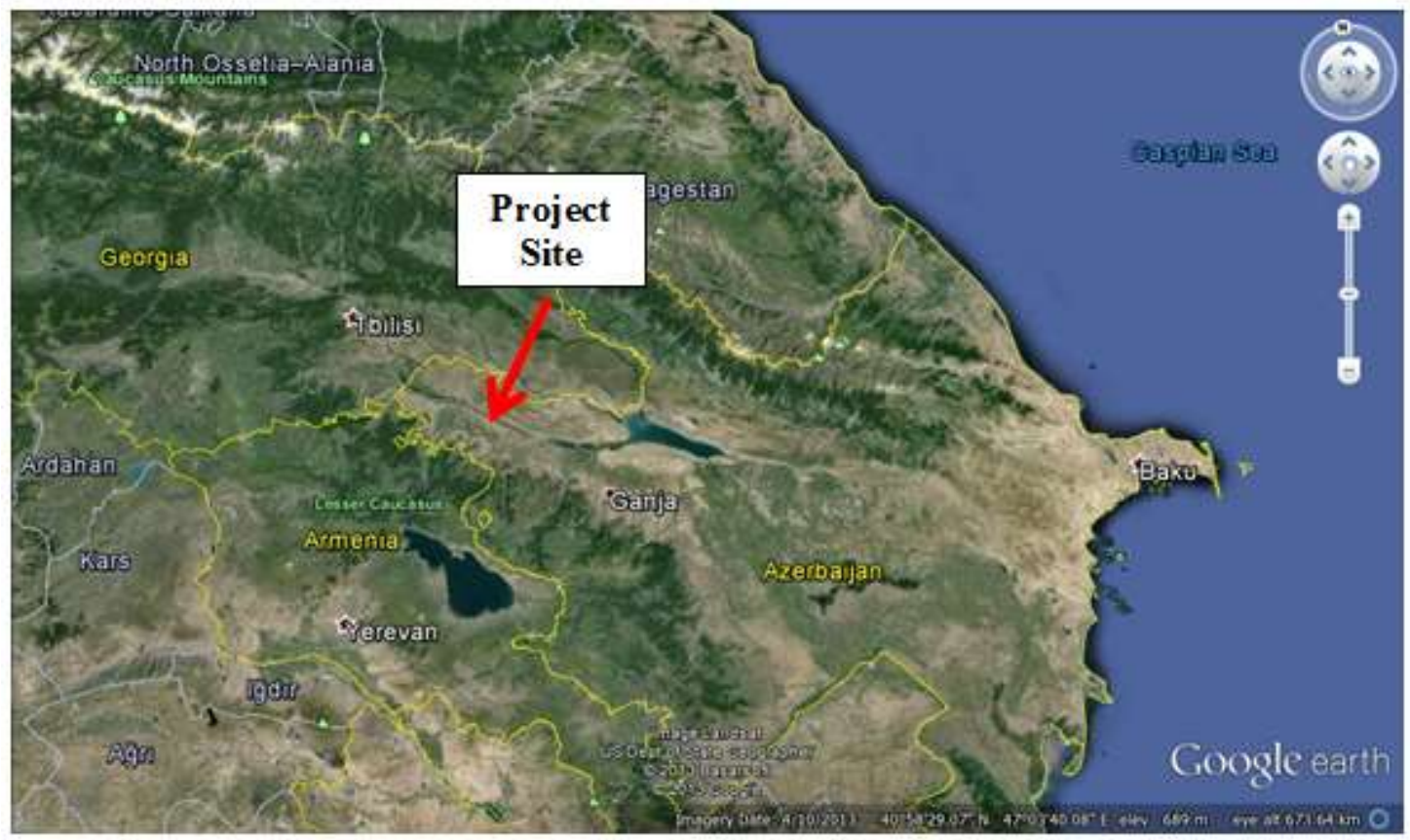

Figure 1. Location of the project site

After tiny cracks and tiltings were observed on the built structures as an indicator of a severe settlement problem, a detailed investigation program was started based on time dependent settlement measurements recorded at different points of the site. The measurements revealed that the rate of settlements were very high during rainy seasons while it was almost flat during dry seasons indicating a very obvious collapse behavior.

\section{SITE INVESTIGATIONS}

The author was informed that, prior to the construction of cement plant, a company drilled 184 boreholes which were 15 to 25 meters long. The investigated area is located at a rural part of the North Azerbaijan where most of the remaining structures are single-storey houses. Consequently, there was no former information, investigation or a case history about the collapse potential of the soil in the region. As a result, care was not given to collapse potential but rather to bearing capacity issues and no experiments were carried out to investigate the collapse potential. Using the information obtained from this investigation, a design company designed the foundations and suggested $16 \mathrm{~m}$ long piles to carry the structures to be built. Another investigation was conducted by a local company containing 10 CPT (Cone Penetration Test) tests in $45 \mathrm{~m}$ deep boreholes and 7 CPT tests in 16-24m deep boreholes to check the design calculations.

The collapse susceptibility of the base soil could not be identified despite the abovementioned site investigations and more than 1400 conventionally designed friction piles $(16 \mathrm{~m}$ in length, each designed to carry a vertical load of $1000 \mathrm{kN}$ ) were constructed at the site. The construction had started in dry season and large settlements were observed at pile heads in a very short time at the beginning of the wet season, even before making any construction on the piles at some locations. After these observations, the construction was immediately halted and another company was assigned to conduct a new investigation program in order to determine the physical and mechanical characteristics of the base soil. A total of 34 boreholes with depths varying from $39.5 \mathrm{~m}$ to $49.55 \mathrm{~m}$ were drilled for this purpose. General view of the plant during construction and layouts of the boreholes are shown in Fig.2 and Fig.3. Since the last mentioned investigation was the most detailed, reliable, up-to-date and the only complete one among others, the results of this investigation were used together with the measurements for the evaluations presented in this study. 


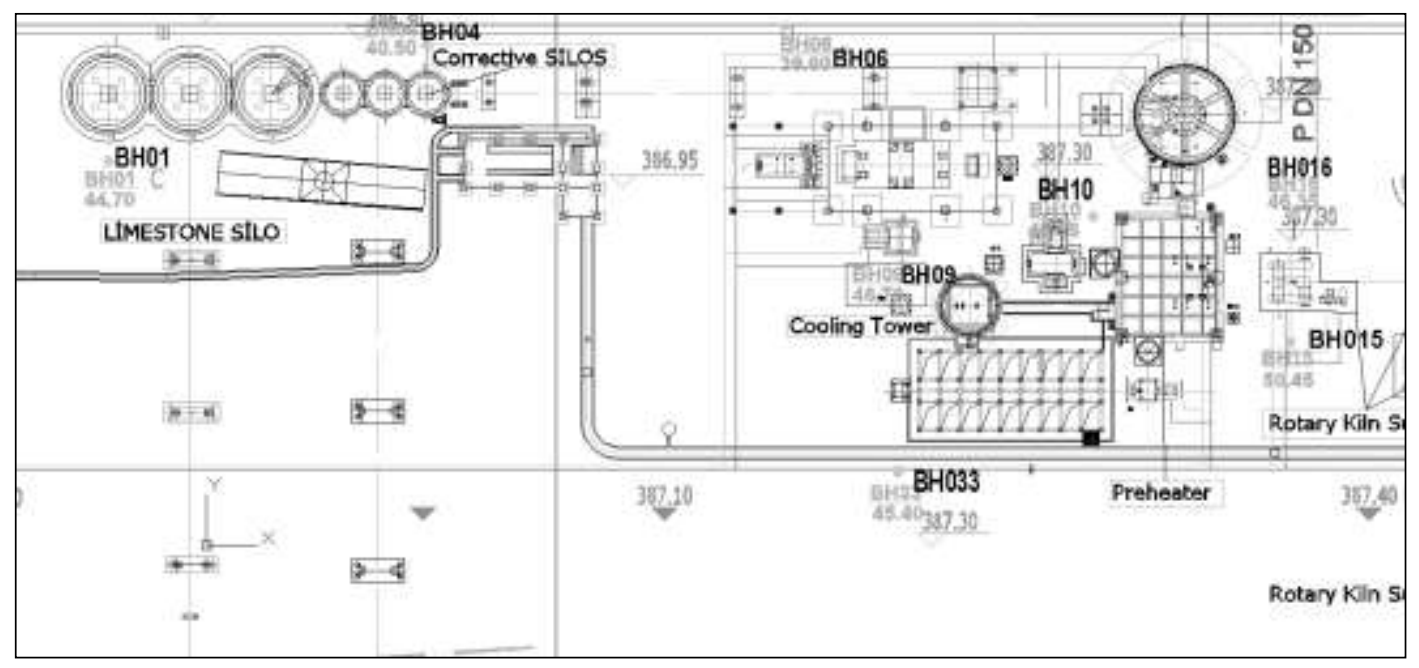

(a) Borehole locations on the west side of the construction area

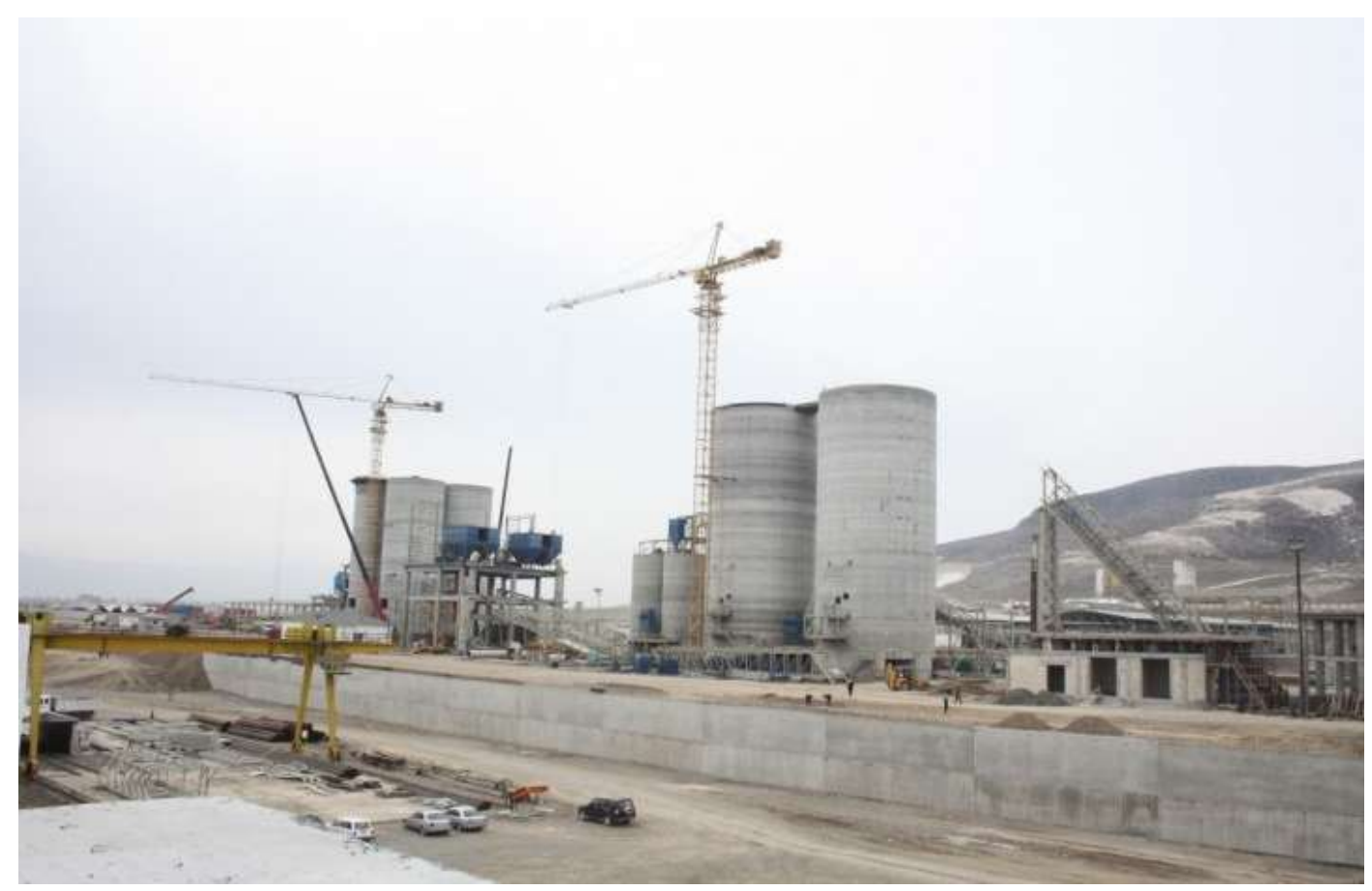

(b) A view during construction from west side of the plant

Figure 2 . West side of the construction area $(\approx 850 \mathrm{~m} \times 900 \mathrm{~m})$ 


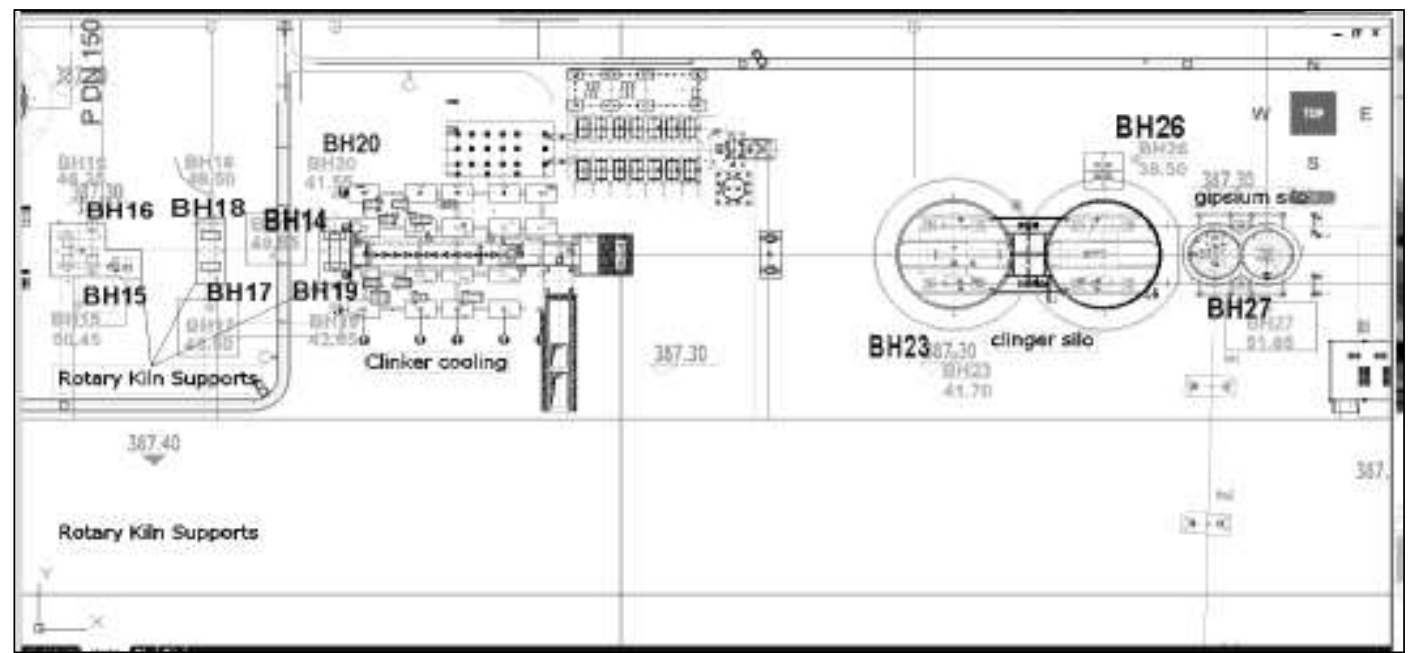

(a) Borehole locations on the east side of the construction area

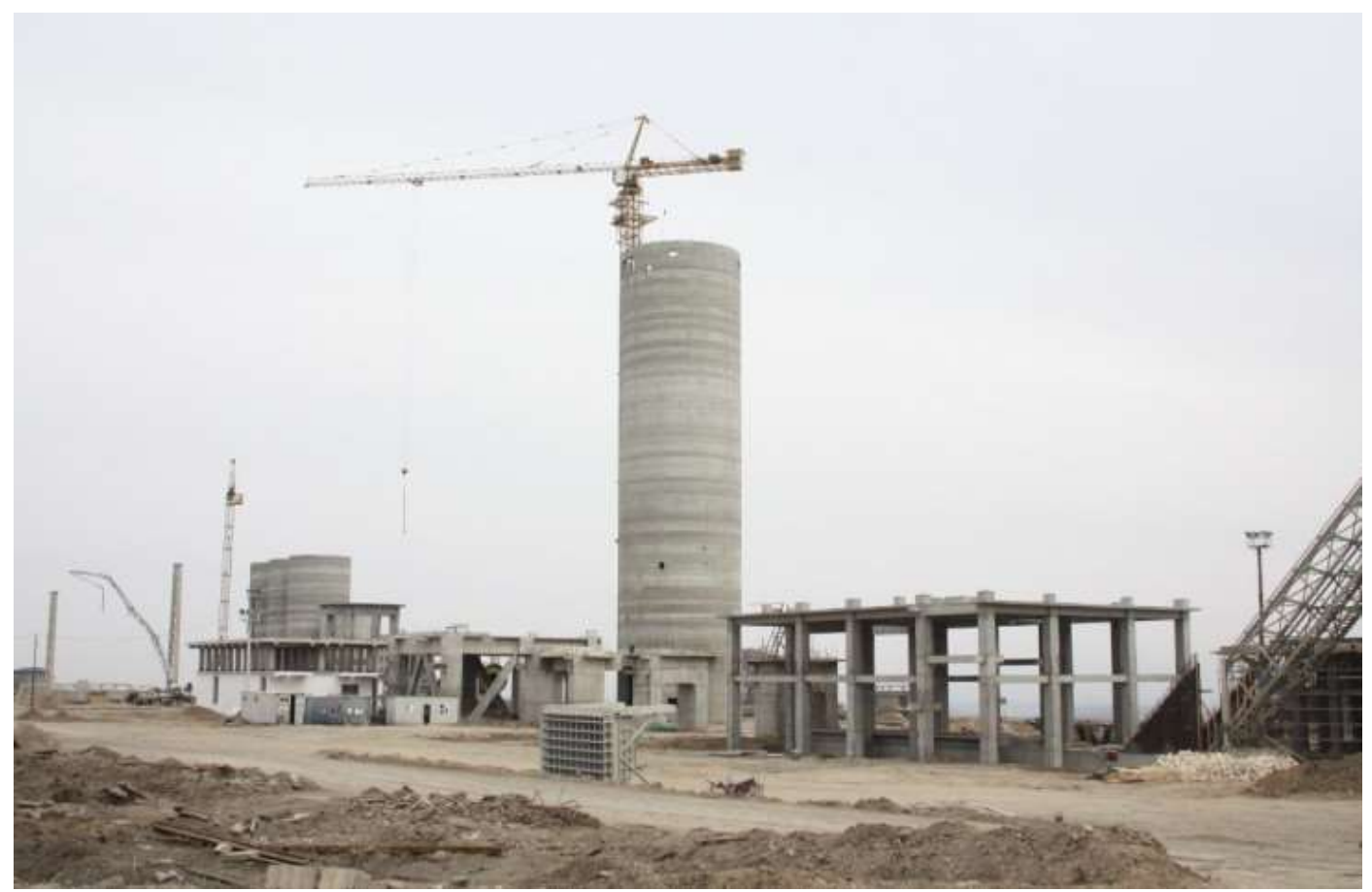

b) A view during construction from east side of the plant

Figure 3. East side of the construction area $(\approx 850 \mathrm{~m} \times 550 \mathrm{~m})$

\section{DISCUSSIONS}

According to the last soil investigation, the soil formation of the area is of Quaternary origin and composed of alluvial-dealluvial-proalluvial complex. Lithologically it consists of soft cohesive clayey soils (clay, clay loam, loamy sand). In the composition of these soils various sized rolled soil fragments, different salts, gypsum mixtures and mica are present. These soils are carbonated and often dusty, sometimes loess-like. In some places of the area, at different depths, coarse limestone pieces are found. An examination of borehole logs shows that SPT (Standard Penetration Test) blow counts can be as low as $\mathrm{N}=7-12$ in the first $18 \mathrm{~m}$ (at maximum) from ground surface and increases below this depth. The representative physical and mechanical characteristics of the base soil within this depth obtained from the experiments conducted on samples are summarized below in Table 1. 
Table 1. Summary of representative physical and mechanical properties of the soil

\begin{tabular}{|rcccccccccc|}
\hline $\mathbf{Q}\left(\mathbf{g} / \mathbf{c m}^{3}\right)$ & Qdry $\left(\mathbf{g} / \mathbf{c m}^{3}\right)$ & Gs & Cu & $\mathbf{W n}_{\mathbf{n}}(\mathbf{\%})$ & $\mathbf{L L}(\%)$ & PI (\%) & $\mathbf{e ~ ( \% )}$ & $\mathbf{n ~ ( \% )}$ & $\mathbf{c ~ ( k P a )}$ & $\mathbf{\Phi ~ ( 0 )}$ \\
\hline 1.95 & 1.60 & 2.72 & 15 & 22 & 39 & 21 & 74 & 42.5 & 34 & 20 \\
\hline
\end{tabular}

According to the site observations, the soil which was evaluated as a loose soil deposit according to the SPT test results was seen to be stiff enough and cemented in dry condition. The method suggested by Das (2015) was used initially to evaluate the collapse susceptibility of the soil based on the data obtained from the tested soil samples. In this method, a line representing the equation given in Eq.1 separates the collapsing and non-collapsing soils. The obtained dry unit weight and liquid limit is plotted on the graph for each sample and if the point is above the line, the sample is classified as non-collapsible while it is classified as collapsible if it falls below this line. When dry unit weight was plotted against the liquid limit for the tested samples, only two out of thirty samples were located on this line while only one sample fell below this line. All of the other points (90\% of the tested samples) fell to the non-collapsing region (Fig.4). Also, many other methods suitable to be utilized with the available data, to estimate the collapse potential $(\mathrm{CP})$ of the soil have been investigated. The soil was evaluated as collapsible by some of the methods while other methods were classifying the soil as non-collapsible or in the transition zone. Only the method suggested by Ayadat and Hanna (2007) indicated the collapse potential clearly. All of these evaluations are summarized in Table 2.

$$
\frac{\mathrm{G}_{\mathrm{s}} \gamma_{\mathrm{w}}}{1+(\mathrm{LL}) \mathrm{G}_{\mathrm{s}}}
$$

Table 2. Evaluation of collapse potential by different methods

\begin{tabular}{|c|c|c|c|}
\hline Method & Reference & Calculation & Evaluation \\
\hline $\begin{array}{l}\text { Collapsible if: } \\
n>40 \%\end{array}$ & Feda (1966) & $\mathrm{n}=42.5 \%$ & $\begin{array}{l}\text { Collapsible but } \\
\text { close to limit } \\
\text { value }\end{array}$ \\
\hline $\begin{array}{l}\text { Collapsible if: } \\
n>40 \% \text { \& } \mathrm{W}_{n}<30 \%\end{array}$ & Minkov (1977) & $\begin{array}{l}\mathrm{n}=42.5 \% \\
\mathrm{~W}_{\mathrm{n}}=22 \%\end{array}$ & $\begin{array}{l}\text { Collapsible but } \\
\text { close to limit } \\
\text { value }\end{array}$ \\
\hline $\begin{array}{l}\mathrm{Cu} \leq 4 \rightarrow \text { Non-Collapsible } \\
4<\mathrm{Cu}<12 \rightarrow \text { Transition Interval } \\
\text { (Collapse may occur) } \\
\mathrm{Cu} \geq 12 \rightarrow \text { Collapsible }\end{array}$ & $\begin{array}{c}\text { Ayadat and } \\
\text { Belouahri (1996) }\end{array}$ & $\mathrm{Cu}=10$ & $\begin{array}{l}\text { Transition } \\
\text { Interval }\end{array}$ \\
\hline $\begin{array}{l}\text { Collapsible if: } \\
\mathrm{PI}<20 \% \text { \& } 15<\mathrm{W}_{n}<35\end{array}$ & $\begin{array}{c}\text { Ayadat and Ouali } \\
\text { (1999) }\end{array}$ & $\begin{aligned} \mathrm{PI} & =21 \\
\mathrm{Wn}_{\mathrm{n}} & =22 \%\end{aligned}$ & $\begin{array}{c}\text { Non-Collapsible } \\
\text { but close to limit } \\
\text { value }\end{array}$ \\
\hline $\begin{array}{l}C P=a(\gamma \text { dry }-15.27)+b w_{n}+17 \\
a=-0.036 C u-1.379 \\
b=0.0006 C u^{2}-0.089 C u+1.3 \\
\text { Collapsible if } C P>1\end{array}$ & $\begin{array}{c}\text { Ayadat and Hanna } \\
\text { (2007) }\end{array}$ & $\begin{array}{c}\mathrm{Cu}=10 \\
\gamma_{\mathrm{dry}}=15.7 \mathrm{kN} / \mathrm{m}^{3} \\
\mathrm{~W}_{\mathrm{n}}=22 \% \\
\text { So, } \mathrm{CP}=26.6\end{array}$ & Collapsible \\
\hline $\begin{array}{l}\text { Collapsible if: } \\
x<\frac{\mathrm{G}_{\mathrm{s}} \gamma_{\mathrm{w}}}{1+(\mathrm{LL}) \mathrm{G}_{\mathrm{s}}} \\
\text { Non-Collapsible if: } \\
x>\frac{\mathrm{G}_{\mathrm{s}} \gamma_{\mathrm{w}}}{1+(\mathrm{LL}) \mathrm{G}_{\mathrm{s}}}\end{array}$ & Das (2015) & $\begin{array}{l}\text { Data plotted in } \\
\quad \text { Fig. } 4\end{array}$ & $\begin{array}{l}90 \% \text { Non- } \\
\text { Collapsible }\end{array}$ \\
\hline
\end{tabular}

As mentioned above, the collapse potential of the soil could not be identified clearly by most of the methods which were suitable to be used with the available data. However, the appearance and behavior 
of the soil completely changes when it is subjected to water. As it can be seen in Fig.5, a stiff soil block starts to disintegrate rapidly when inundated with water and turns in to mud just in a few minutes. The complete disintegration of an approximately $10 \times 10 \mathrm{~cm}$ sample took around seven minutes during this observational experiment.

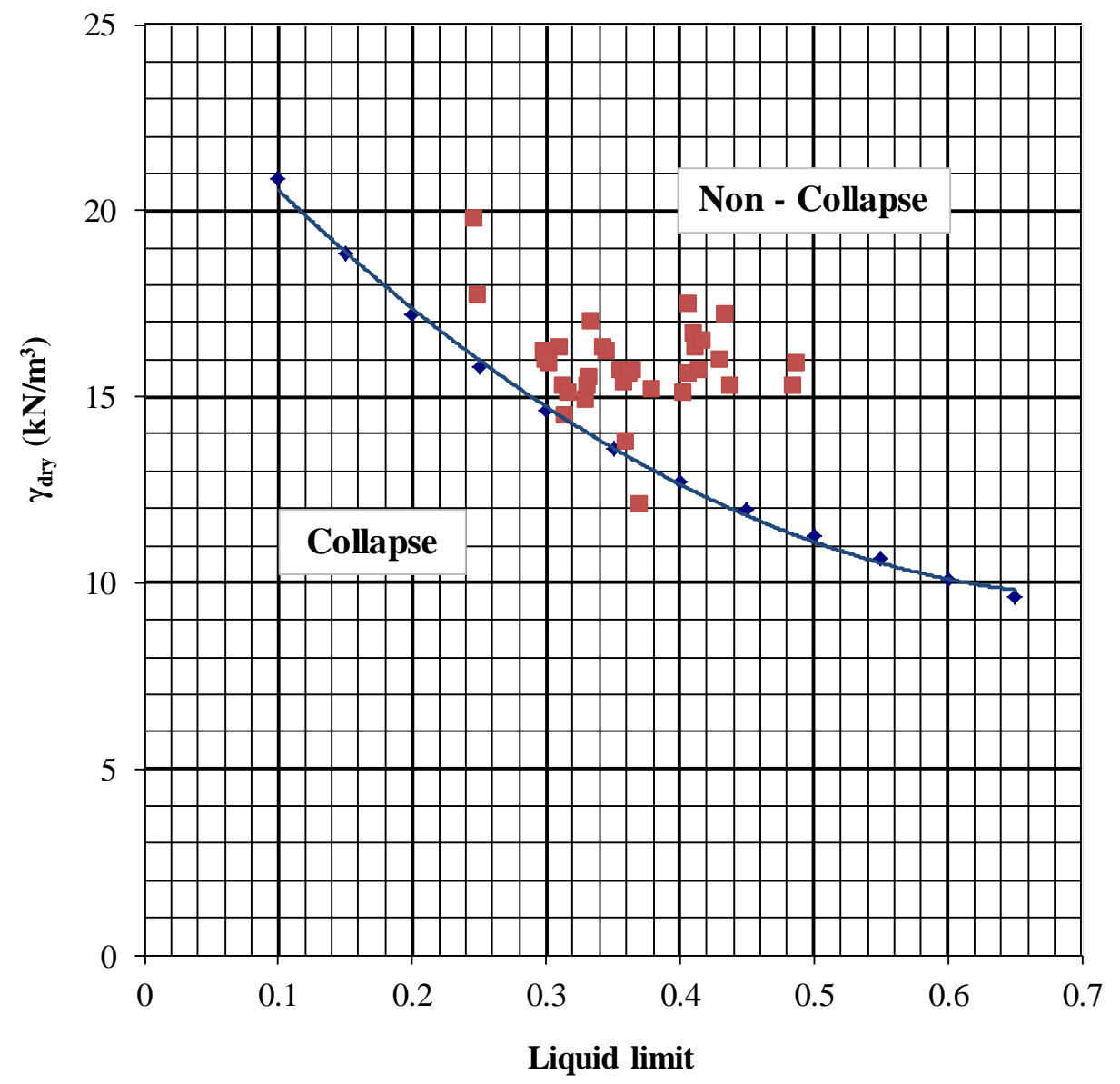

Figure 4. Collapse susceptibility of soil samples of the construction area (Das, 2015)

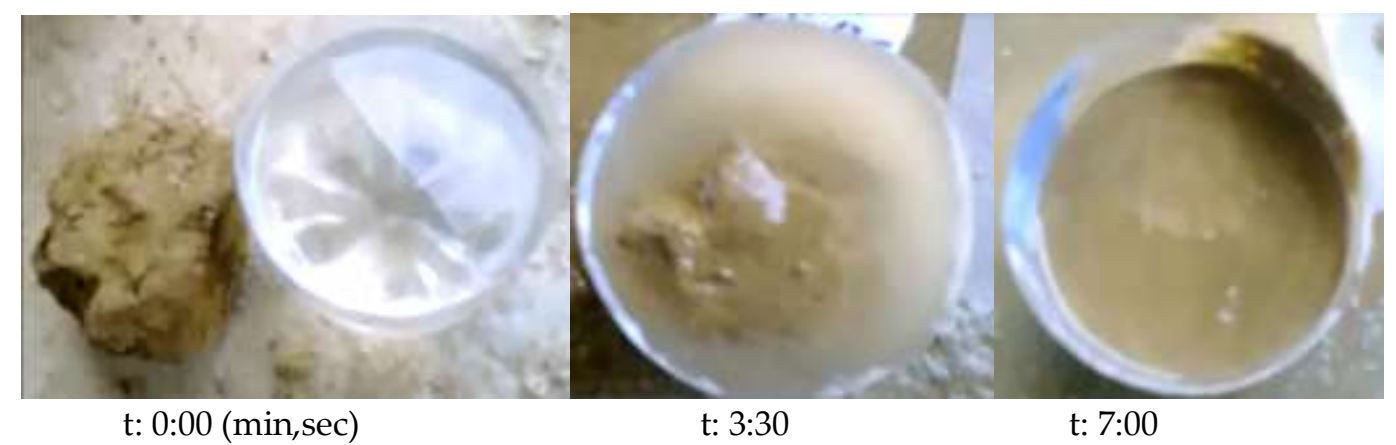

Figure 5. Change of soil state when subjected to water

The collapse of the subsoil was most clearly observed under clinker silo. As it can be seen from settlement measurements under clinker silo (Fig.6), the rate of settlements increased during rainy seasons while they almost stabilized during dry seasons. The total collapse at this location was on the order of $120 \mathrm{~mm}$ which resulted in significant tilting of the structure (Fig.7). 


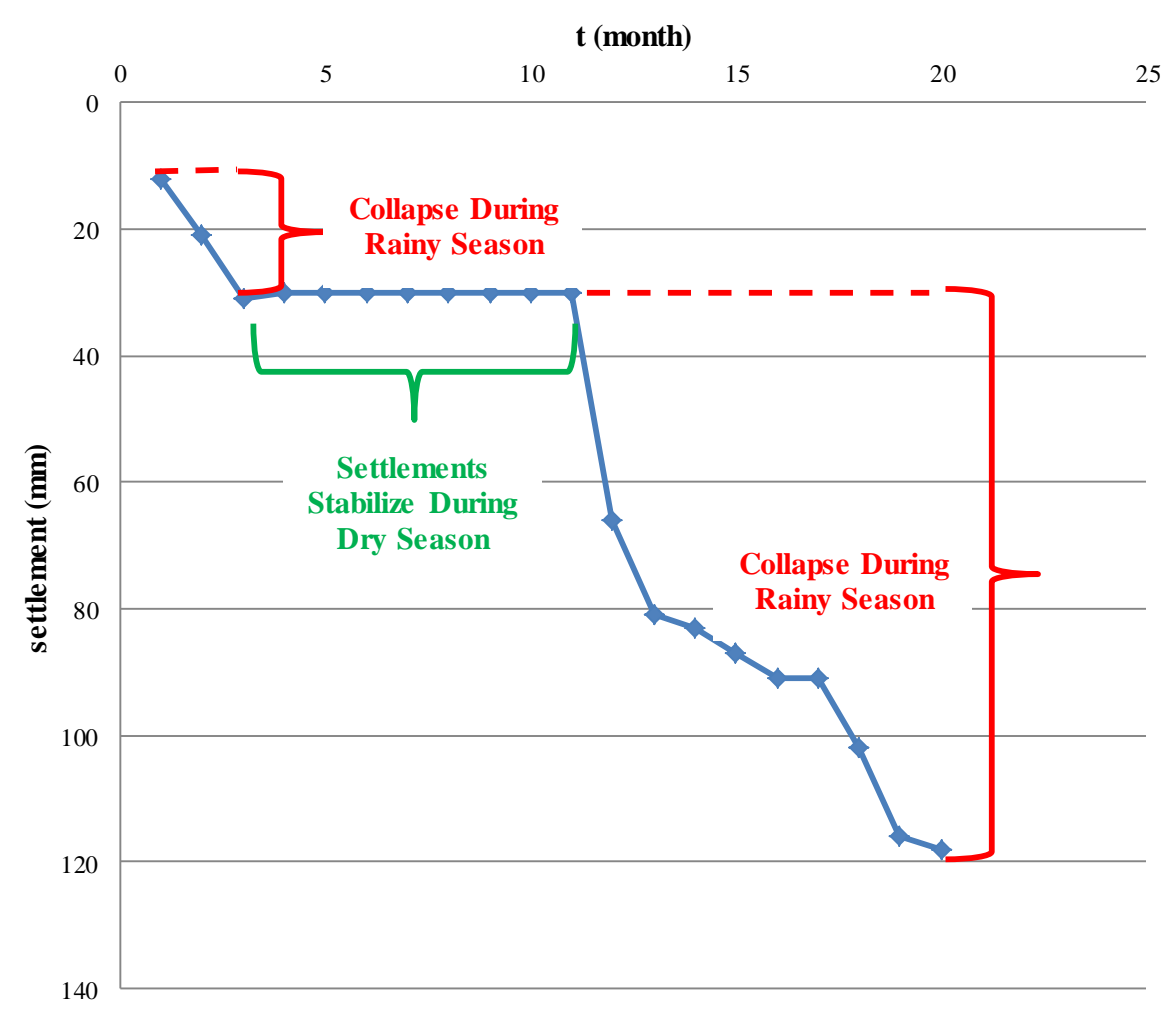

Figure 6. Time-Settlement plot for clinker silo

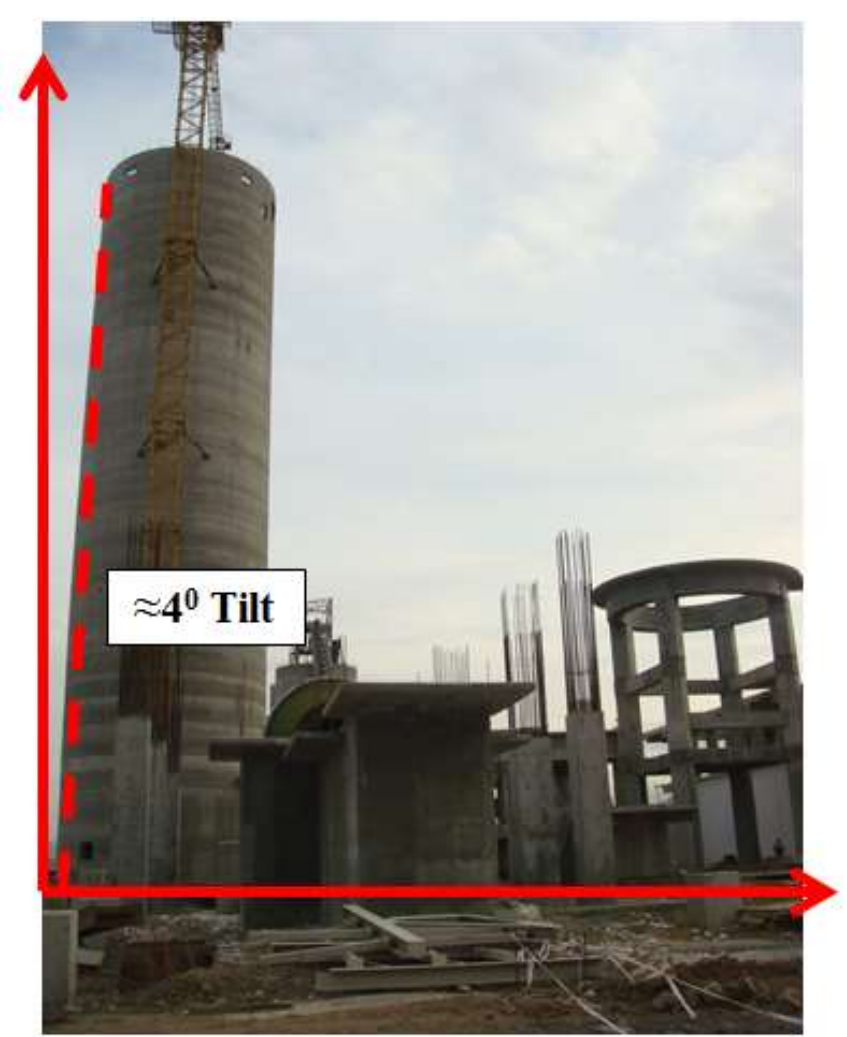

Figure 7. Tilting of clinker silo

The reinforced concrete foundations were cracked due to collapse of base soil even before the construction of the structures which they were planned to carry. The settlements beneath the foundation 
of the raw mill fan of the cement plant were measured at four corners and it was seen that the foundation had collapsed on the order of $80 \mathrm{~mm}$ (Fig. 8) which led to cracking of the foundation at different points (Fig. 9). Similar behavior and extensive settlements were measured at almost all important parts of the cement plant construction. The construction had been stopped for almost 2 years during which extensive site investigations were executed. The cost of underestimating the collapse probability of the base soil was tremendous since the opening of the plant was delayed for 2 years and some of the constructed facilities had to be demolished and reconstructed after soil improvement. Also 1400 piles constructed at the beginning of the project were completely sinked in to the soil and could not be used to support the structures any more resulting in another significant financial loss.

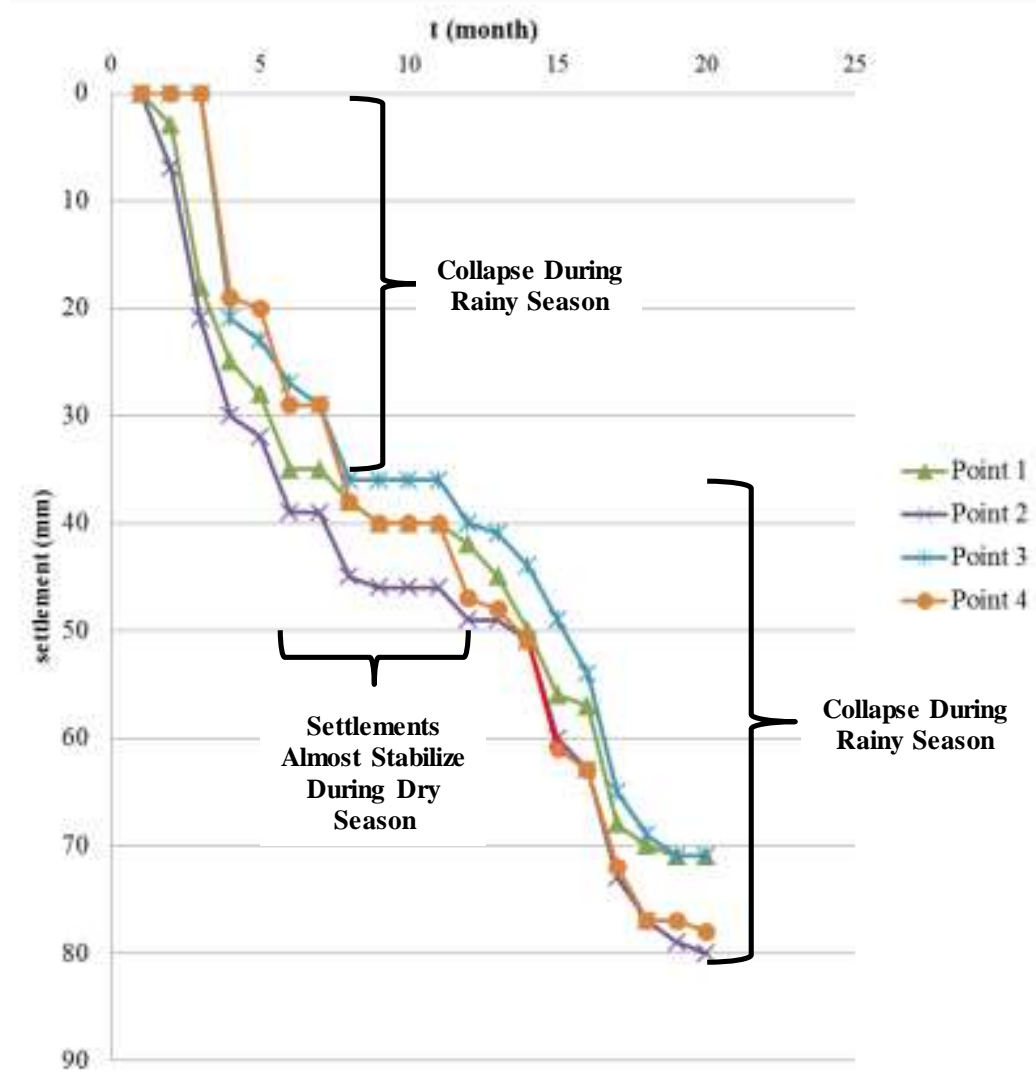

Figure 8. Settlement measurement beneath raw mill fan foundation
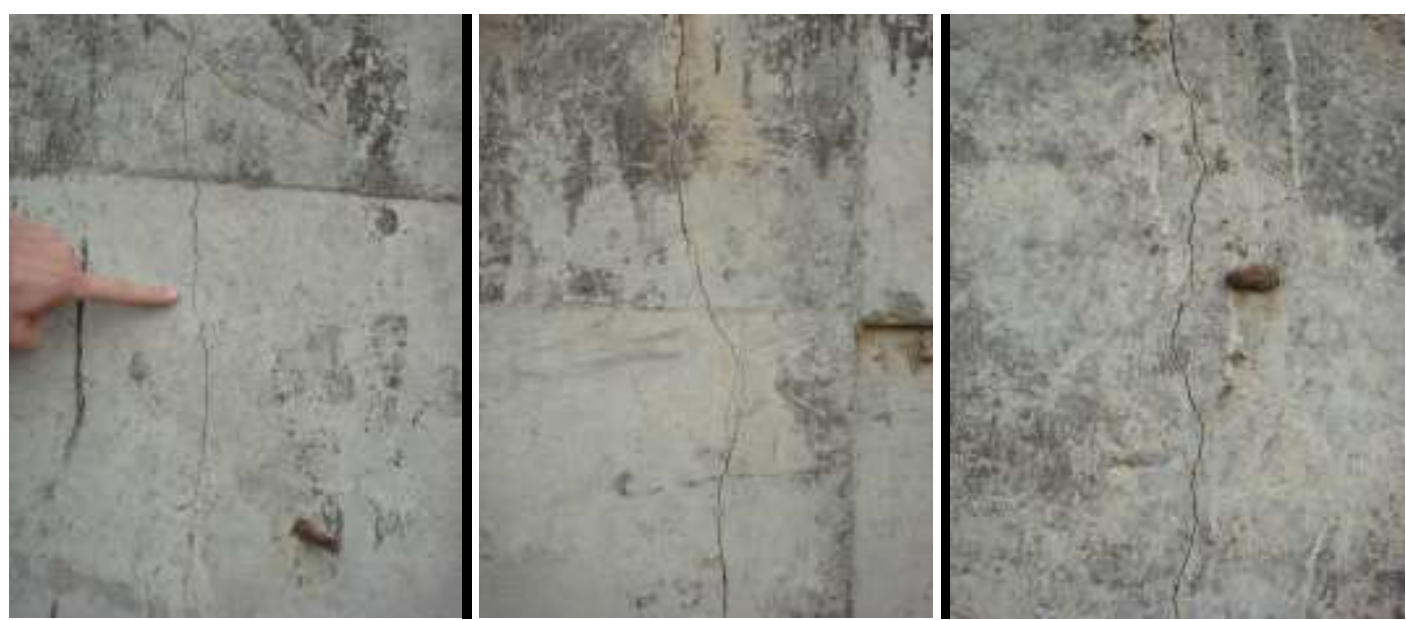

Figure 9. Concrete cracking in foundations due to collapse settlements 


\section{CONCLUSIONS}

In this study, the excessive settlements of collapsible soils observed at a cement plant construction site in north Azerbaijan and its effects on the constructed facilities were discussed. The soil appears to be very hard and highly cemented in dry condition but turns into mud in a few minutes when subjected to water. Sudden collapses occur in rainy seasons and rate of settlements decrease during dry periods.

During the initial site investigations, no studies were carried out about the collapse potential of the base soil but the investigations were focused on bearing capacity calculations. The foundations were designed with $16 \mathrm{~m}$ long friction piles based on the conventional bearing capacity and settlement calculations. This mistake resulted in waste of huge investment and time. The constructed facilities have tilted and settled. The construction had been stopped for almost 2 years and most of the constructed parts of the cement plant had to be either reconstructed or repaired.

The construction area is rural but will be subject to a very fast urbanization in a short time due to new industrial investments. All above mentioned facts reveal that the practice for site investigations should be modified for the region. Tests and observations should be carried out on collapse potential as well as the bearing capacity and settlement issues, not to skip the risk for the other construction activities as done in this case. Although the soil properties were investigated in detail in the latest site investigation, still the collapse potential could not be determined clearly by most of the indirect methods. These methods are giving different results since the data sets used in developing these methods were obtained from samples taken from different locations of the world. However, the soil properties of the investigated region are not fully compatible with most of the presented methods. The important lesson learned from this case is that the geotechnical engineer should not only always rely on the indirect methods based on soil properties like dry density, liquid limit, plasticity index, void ratio and etc. to determine the collapse susceptibility of a soil especially when the parameters utilized to check the collapse potential are close to the limiting values given in these methods. It is strongly recommended to investigate the collapse potential experimentally in such situations. Otherwise, the engineer may skip the potential problems which may result in significant damage of structures and huge costs as seen in this case.

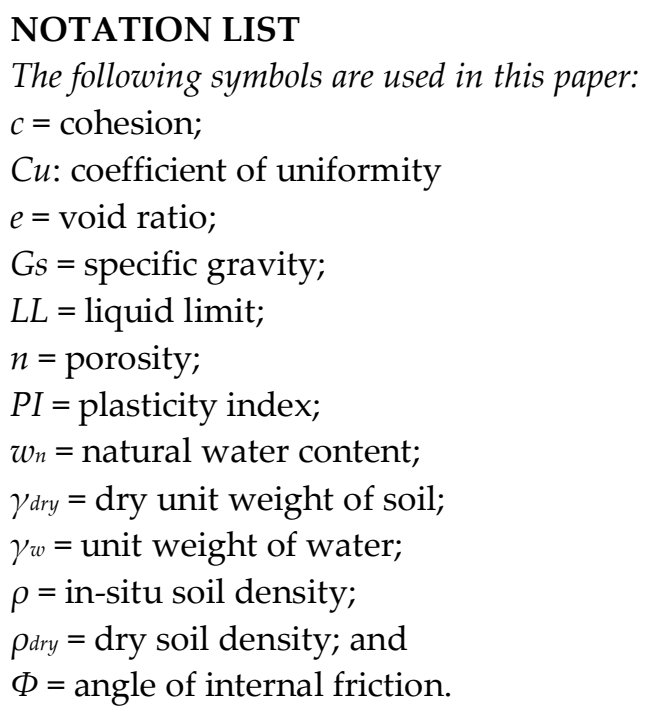

\section{ACKNOWLEDGMENTS}

Prof. Dr. M. Yener Özkan is sincerely acknowledged for his continuous support and encouragement. The engineers and investors involved in the construction of the discussed cement plant are also acknowledged for their cooperation during the study of the author. 


\section{REFERENCES}

Ayadat, T., Belouahri, B., 1996, "Influence du coefficient d'uniformité sur l'amplitude et le taux de l'affaissement des sols", Revue française de géotechnique, Vol. 76, pp. 25-34.

Ayadat, T., Hanna, A., 2007, "Prediction of Collapse Behaviour in Soil”, Revue Européenne de Génie Civil, Vol. 11, No. 5, pp. 603-619.

Ayadat, T., Ouali, S., 1999, "Identification des sols affaissables basée sur les limites d'Atterberg”, Revue française de géotechnique, Vol. 86, pp. 53-56.

Benedini, M., Cleere H., 2005, "Report of the UNESCO-ICOMOS Monitoring Mission to ABU MENA (Egypt)"

Das, B., 2015, Principles of Foundation Engineering, Cengage Learning, Boston, USA.

El-Ehwany, M., Houston, S., 1990, "Settlement and Moisture Movement in Collapsible Soils", Journal of Geotechnical Engineering, Vol. 116, No. 10, pp. 1521-1535.

Feda, J., 1966, "Structural Stability of Subsiding Loess from Prahadejvice", Engineering Geology, Vol. 1, pp. 201-219.

Gibbs, H. J., Bara, J. P., 1967, "Stability Problems of Collapsing Soil", Journal of Soil Mechanics and Foundation Engineering, Vol. 93, pp. 577-594.

Grigoryan, A. A., 1991, "Construction on Loess Soils", Soil Mechanics and Foundation Engineering, Vol. 28, No. 1, pp. 44-49.

Handy, R. L., 1973, "Collapsible Loess in Iowa", Soil Science Society of America Journal, Vol. 37, No. 2, pp. 281-284.

Herle, I., Herbstová, V., Kupka, M., Kolymbas, D., 2010, "Geotechnical Problems of Cultural Heritage due to Floods", Journal of Performance of Constructed Facilities, Vol. 24, SPECIAL ISSUE: Flood Impact to Heritage Structures, pp. 446-451.

Hormdee, D., 2008, "Investigation on Collapse Potential of Loess Soil", Eighteenth International Offshore and Engineering Conference, Vancouver, 579-581, 6-11 July 2008.

Houston, S., Houston, W., Lawrence, C., 2002, "Collapsible Soil Engineering in Highway Infrastructure Development", Journal of Transportation Engineering, Vol. 128, No. 3, pp. 295-300

Houston, S., Houston, W., Spadola, D., 1988, "Prediction of Field Collapse of Soils Due to Wetting", Journal of Geotechnical Engineering, Vol. 114, No. 1, pp. 40-58.

Larionov, A.K., 1965, "Structural Characteristics of Loess Soils for Evaluating their Constructional properties", $6^{\text {th }}$ international Conference on SMFE, Montreal, Vol. 1, 64-68, 8-15 September 1965.

Lawton, E., Fragaszy, R., Hetherington, M., 1992, "Review of Wetting-Induced Collapse in Compacted Soil", Journal of Geotechnical Engineering, Vol. 118, No. 9, pp. 1376-1394.

Lin, Z., Liang, W., 1982, "Engineering Properties and Zoning of Loess and Loess-like Soils in China", Canadian Geotechnical Journal, Vol. 19, No. 1, pp. 76-91.

Minkov, M., 1977, "Deformation Properties of Bulgarian Loess Soils", 9th International Conference on SMFE, Tokyo, Vol. 1, 215-218, 11-15 July 1977.

Priklonski, V.A., 1952, “Gruntoredenia-Vtoraid chest. Gosgeolzdat”, Moscow, U.S.S.R.

White, D., Mekkawy, M., Sritharan, S., Suleiman, M., 2007, "Underlying" Causes for Settlement of Bridge Approach Pavement Systems", Journal of Performance of Constructed Facilities, Vol. 21, No. 4, pp. 273-282. 